\title{
Retraction Note: New applications of Schrödingerean Green potential to boundary behaviors of superharmonic functions
}

Kai Lai ${ }^{1}$, Jing $\mathrm{Mu}^{2}$ and Hong Wang ${ }^{3 *}$

The original article can be found online at https://doi.org/10.1186/ s13661-017-0746-4

*Correspondence: h.wang.maths@foxmail.com ${ }^{3}$ Department of information engineering, Hainan Technology and Business College, Haikou, 570203, China

Full list of author information is

available at the end of the article

\section{Springer}

\section{Retraction Note}

The Editors-in-Chief have retracted this article because it shows significant overlap with an article by different authors that was simultaneously under consideration with another journal [1]. The article also shows evidence of authorship manipulation and peer review manipulation. The authors have not responded to correspondence regarding this retraction.

\footnotetext{
Author details

${ }^{1}$ College of Computer and Information Engineering, Henan University of Economics and Law, Zhengzhou, 450011, China. ${ }^{2}$ School of Management, Tianjin Polytechnic University, Tianjin, 450063, China. ${ }^{3}$ Department of information engineering, Hainan Technology and Business College, Haikou, 570203, China.
}

\section{Publisher's Note}

Springer Nature remains neutral with regard to jurisdictional claims in published maps and institutional affiliations.

Published online: 19 July 2021

\section{References}

1. Luan, K., Vieira, J.: Poisson-type inequalities for growth properties of positive superharmonic functions. J Inequal Appl 2017, 12 (2017). https://doi.org/10.1186/s13660-016-1278-7 (c) The Author(s) 2021. This article is licensed under a Creative Commons Attribution 4.0 International License, which permits use, sharing, adaptation, distribution and reproduction in any medium or format, as long as you give appropriate credit to the original author(s) and the source, provide a link to the Creative Commons licence, and indicate if changes were made. The images or other third party material in this article are included in the article's Creative Commons licence, unless indicated otherwise in a credit line to the material. If material is not included in the article's Creative Commons licence and your intended use is not permitted by statutory regulation or exceeds the permitted use, you will need to obtain permission directly from the copyright holder. To view a copy of this licence, visit http://creativecommons.org/licenses/by/4.0/. 